\section{ECONOMICS}

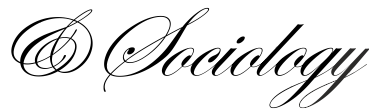

Taresh A, A., Sari, D. W., \& Purwono, R. (2021). Analysis of the relationship between income inequality and social variables: Evidence from Indonesia. Economics and Sociology, 14(1), 103-119. doi:10.14254/2071-789X.2021/14-1/7

\title{
ANALYSIS OF THE RELATIONSHIP BETWEEN INCOME INEQUALITY AND SOCIAL VARIABLES: EVIDENCE FROM INDONESIA
}

\begin{abstract}
Abdulrahman Taresh A.
Faculty of Economics and Business, Airlangga University, Indonesia

E-mail:abdt713@yaboo.com

ORCID 0000-0002-4217-7512
\end{abstract}

Dyah Wulan Sari

Faculty of Economics and Business, Airlangga University, Indonesia

E-mail:

dyah-wulansari@feb.unair.ac.id

ORCID 0000-0003-3567-6513

Corresponding author

Rudi Purwono

Faculty of Economics and Business, Airlangga University, Indonesia

E-mail:

rudipumvono@ffeb.unair.ac.id

Received: March, 2020

1st Revision: July 2020

Accepted: February, 2021

DOI: $10.14254 / 2071$ -

789X.2021/14-1/7

JEL Classification: A14, O15
ABSTRACT. This study tries to analyse the relationship between income inequality and social variables to provide additional empirical input on the related structural model. To achieve these objectives, this study uses the cointegration and long-run structural vector auto-regression (SVAR) for the panel data on 33 provinces in Indonesia over the 2005-2018 period. The study concludes that income inequality has a positive impact on population growth, unemployment, and poor health, whereas it also has a negative effect on education, human development, and urbanisation growth. Population growth, unemployment, poor health and urbanisation growth can increase income inequality, while education and human development index reduce income inequality. Furthermore, increased minimum wages can reduce income inequality, poor health, and increase education and per capita income. This study also found that per capita income has a long-term relationship with income inequality and population.

Keywords: income inequality, social variables, panel cointegration, Indonesia.

\section{Introduction}

Income inequality is a social problem that has more consequences than the economy itself. In the long term it generates social shocks that lead to deterioration of the society welfare, increased poverty and unemployment and a decline in the quality of population's health and education. Thus, eventually it impacts human development. Social variables have a strong 
relationship with income inequality, for instance, population growth which is one of the social variables that is directly related to income inequality. Population growth can be caused by fertility, mortality, and migration, which affects and is affected by income inequality and per capita income. The per capita income that reflects the level of economic welfare means dividing the national income of a country over its population. The economic dependency ratio for several dependents from a person affects the size of a family's per capita income; thus, high level of economic dependency increases income inequality. Besides, population growth directly affects labour supply. Therefore, high rates of population growth can lead to increased income inequality because most of the workforce tends to work under low wages, especially in the traditional sectors in the economies of developing countries like Indonesia.

Indonesia is one of the developing countries with a large size of population. It suffers from high-income inequality. Indonesia's Gini index as a measure of inequality has changed from 0.35 (2005) to 0.41 (2012) and then to 0.39 (2018). The report by Oxfam Indonesia and the international NGO Forum on Indonesia Development (INFID) shows that the richest of rich people in Indonesia have greater wealth than the wealth of the $100 \mathrm{mln}$ poorest people in Indonesia (Gibson, 2017). The unemployment rate in Indonesia is 5.34\% while the average minimum wage was around US\$257 per month in 2018. In contrast, per capita income was US $\$ 3,927$ in 2018, so Indonesia's GDP per capita is the second-lowest among the G20 countries. The study by Fazaalloh (2019) shows that when Indonesian economic growth is increasing, income inequality also goes higher.

Indonesia which is the fourth largest population in the world has large population of a productive age, however, but it also has high unemployment rate that can be a barrier to an increase in the minimum wage and to the distribution of income. Income distribution has become one of the key goals for Indonesian government which is currently focusing on infrastructure and human development. Indonesia's Human Development Index in 2018 increased to 0.713 . This rate is the highest as compared to the previous years. Wicaksono et al. (2017) who examined education and the employment sector suggested that this variable is a significant contributor to income inequality in Indonesia while infrastructure can reduce income inequality indirectly (Nugraha et al., 2020). Urbanisation growth also can reduce income inequality, whereas high wages in the urban economy will reduce income inequality (Kuznets, 1955). At the same time,urban living is characterised by low fertility and high human development as compared to rural areas. However, in Indonesia, high income inequality is actually taking place in urban areas, it is recorded at 0.40 in urban areas while in rural areas it was 0.32 in 2018.

Determination of the nature and direction in the relationship between social variables and income inequality has been the subject of debate among both researchers and policymakers. The core problem with the relationship between these variables is whether income inequality impedes social development, or should the policy of social development takes precedence as the first policy to reduce income inequality. This study investigates this two-way relationship of whether higher social development contributes to more equitable distribution of income and/or equitable distribution of income contributes to the achievement of social welfare.

The previous studies have discussed the relationship between social variables and income inequality separately. Therefore, this study aims to analyse the relationship between income inequality and social variables more broadly. The models used to meet these objectives are panel co-integration and structural vector auto-regression (SVAR) long-run models. The main focus of the models is to examine the co-integration and the direction of long-term relationships through the results of impulse responses between the variables under study using panel data on 33 provinces in Indonesia over the period of 2005-2018. 


\section{Literature review}

The income inequality explains by Kuznets $(1950,1955)$, states that in the early stages of growth, the high Gini coefficients reducing resources for categories that save and invest more than others. While improvements in the advanced stages of growth are due to the substitution of human capital, replacing physical capital as a source of growth. Therefore, the relationship between social variables and income inequality is a long-term relationship. Kuznets (1963) explains that the long-term relationship between income per capita and income inequality is negative, where at the advanced stage of growth is a high level of development, there is an increase in wages, and most people move to urban areas. The study of Thornton (2001) show that a negative relationship corresponds to inverted $U$ shape as hypothesised by Kuznets and that the turning point at inverse $U$ is to occur at relatively low-income levels. While Lise et al. (2014) found that the income inequality has increased significantly with the increase in income.

The relationship between population growth and per capita income has been discussed in several studies. The first study conducted by Becker (1981) has a hypothesis that with increasing income per capita, the population tends to choose to improve the quality of children over the number of children. Increasing costs ranging from the cost of giving birth to raising children will encourage the population to limit the number of children, thereby reducing the birth rate. According to Berg (2001), the inverse relationship between income per capita and population, the greatest of the population will be the smaller of income per capita. Hasan (2010), discussed the causality relationship between population and per capita income in China using a VAR model and found evidence that in the long run there is a negative directional relationship between income per capita and population.

Per capita income reduces unemployment and further reduces income inequality. Izraeli and Murphy (2003) found that per capita income to have a statistically significant effect on unemployment. Ciżkowicz et al. (2016) identified the determinants of large disparities in local unemployment rates across Poland by using an extensive panel data-set on the NUTS-4 level and shows that there is low unemployment where there is a high per capita income. Unemployment also has negative consequences for human welfare (Kunze and Suppa, 2017). The high of unemployment can increase the Gini index and make income distribution more unfair (Shahpari and Davoudi, 2014). Cysne and Turchick (2012) claims that there is a positive correlation between unemployment and income inequality, provided the unemployment rate, and the Gini coefficient is not greater than $15 \%$ and $28 \%$ respectively. Then if unemployment is low, it will improve the minimum wage. Agénor and Lim (2018) revealed in the long run, a decrease in the unemployment rate improved in the minimum wage. Adam and Moutos (2006) shows that the reduction of income inequality leads to improve the minimum wages and decrease unemployment, the study also reveals a positive association between unemployment reduction and minimum wages if the changes in the minimum wages are the outcome of political economy considerations.

An increase in the minimum wage can improve income per capita, and an increase in the minimum wage leads to a rise in the level of education and health. Askenazy (2003) examining the impact of minimum wages on growth and welfare for 11 OECD countries, revealed that minimum wages shift the efforts from production to research and development. Hence the minimum wages will accelerate income growth in the long term. Improving living standards for the working class with minimum wages will mean more motivation for better education and health for higher productivity (Ashta, 2013). At the same time, increasing the minimum wage reduces income inequality. Bird and Manning (2008) reflect the minimum wage to be an effective anti-poverty instrument in developing countries such as Indonesia, because the non-poor pay a higher share of the cost of increased minimum wages, the study also found 
that increasing the minimum wages growing net-income of households $21 \%$ in Indonesia. Gindling and Terrell (2010) found that relatively high increases in minimum wages led to poverty reduction, especially extreme poverty. Krozer et al. (2015) captured that raising the minimum wage significantly becomes a major step towards placing income inequality as a top priority on the policymaking agenda. Brito and Kerstenetzky (2019) revealed that minimum wage contributed to a decrease of $38.2 \%$ in the proportion of the poor, and $39.4 \%$ in the intensity of poverty and $40.6 \%$ reduction in the severity of poverty.

This study model illustrates the relationship between income inequality and social variables such as population growth, health, education, human development and urbanisation growth by explainig it in (Figure 1). Increasing population growth will further income inequality, due to low living standards and low per capita income, as the assumption by Malthus, that with an increase in population makes the proportion of poverty increase. The results obtained by Ram (1984) reinforcing estimates of the significant impact of rapid population growth on income inequality. It is also proposed by Lee (2001) that high population growth rates have a direct role in national income inequality. However, income inequality increases population growth, because the low-income segment is more oriented to a high number of children, unlike the rich who prefer to improve the quality of children over quantity. According to Leibenstein (1963), the benefits of additional children decrease when family income raises, which is the reason why low-income families want to have more children. Leibenstein concluded that there was an inverse relationship between family income and fertility. Then the high of population will reduces the standard of living which worsens health.

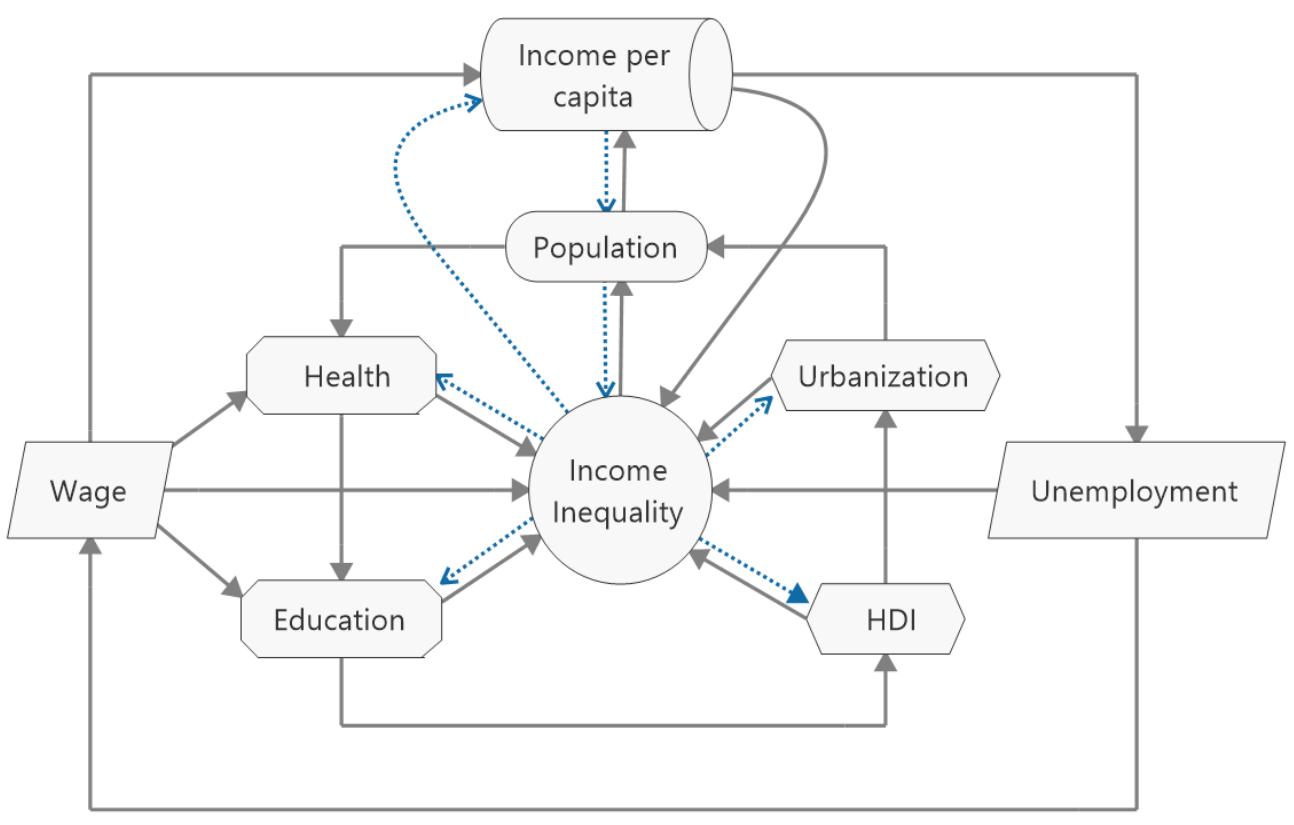

Figure 1. The relationship between income inequality and social variables

No doubt that rising income inequality are causing malnutrition and health, leading to the emergence of disease, therefore increasing health prevention costs. That is why the reciprocal relationship between low income and malnutrition and health, makes not only affect the welfare of the community and also income inequality. We assume that the spread of disease and poor health causes a height in income inequality. And as income inequality increases, health will be deterioration. There is poor public health, where income inequality is greater (Wilkinson and Pickett, 2006). The newer relative income hypothesis is that the health of individuals in a 
society depends on the degree of income inequality in that society. Proponents of the relative income hypothesis show that there is a negative correlation between population health and income inequality because population health decreases with income inequality (Gravelle et al. 2002). Any policy that aims to equalise health, which does not take into account income inequality, will lead to uneven distribution of health (Wildman 2003). Study of Karlsdotter, et al. (2012) emphasised on the importance of health variables and income inequality, and contributed to add to the empirical evidence about the effect of income inequality on population health. Pickett and Wilkinson (2015) afford a group of strong evidence that income inequality affects population health and well-being. As well, Matthew and Brodersen (2018) found that income inequality has a significant relationship with individual physical, behavioural and mental health problems, and often the impact on low-income groups was slightly smaller than the high-income group. Detollenaere et al. (2018) also assessed the strength of the effects of primary care systems on the inverse relationship between income and health inequality, and they confirmed that especially the structural dimensions and continuity of primary care strength could buffer the bumper inverse associations between income inequality and health.

In addition, good health improve education, in another sense, with increasingly health complaints, education will decrease. A related argument is the possibility of reverse causality stating that people who expect to have better health are willing to invest more into education because they expect to live longer giving them more time to reap the investment return (Braakmann, 2011). Where also if the children are in good health, making them increase the level of attendance at school and cognitive development so that later can improve the quality of human resources. Curtin and Nelson (1999) presented proves to show that health status in developing countries will significantly increase the proportion of the population who have at least post-primary education.

Education has a considerable influence on all social and economic fields (Mariana, 2015). Low education and lack of educational opportunities for the poor will increase income inequality. Marks (2015) revealed that education influences family income and that highincome inequality reduces educational opportunities for low-income classes and an increasing gap in educational opportunities between the poor and the rich. Kudasheva et al. (2015) revealed that children from low-income families had access to lower education than children from highincome families in Kazakhstan. Yang and Qiu (2016) found that family investment in education played an important role in explaining income inequality and intergenerational income mobility, and those poor-families had far less participation in higher education. Campo et al. (2016) suggest that income inequality can be overcome with additional education, and find that in general an additional year of education will increase the income earned ethnic minorities of 26.3-28\%. Education also increases the level of human development. Improving the quality of human resources can be through education and so on so that it will significantly impact on the human development index. Then human development has an inverse relationship with income inequality. Human development improves income and wages than will reduce income inequality, and then income inequality reduces human development. Romer (1986) and Lucas (1988), suggests a positive correlation between human resource development activities and income. Among human resource development activities, investment in education has played the role of stimulating income. Focus on human development through increased investment in health, reducing mortality, and improving education will affect income inequality.

The relationship between urbanisation growth and income inequality is an inverse relationship, as assumed by Kuznets (1955), urbanisation growth will be reduced income inequality through the movement of people to urban areas to work in the industrial sector of high wages. However, according to Siddique and Wibowo (2014), if rural communities move to urban areas with little or no education and skills that are in line with the demands of the 
workings of the city company, then these people may be unemployed or may have to be involved in jobs with much lower wages, thus worsening wage inequality, while some studies argue that urbanisation growth exacerbates income inequality. A study conducted by Sulemana et al. (2019) found evidence of a positive relationship between urbanisation growth and income inequality in the region. According to Qiu and Zhao (2019), income inequality is higher in exclusive cities because skilled workers are relatively rare in exclusive cities that can enjoy higher skill premiums. Then, the urban population growth decreases with increasing human development, so urban growth reduces population growth because urban communities prefer to improve the quality of children rather than the number of children as in rural communities. In the opinion of Marx (1818-1883) that population evolution and overpopulation differ between societies, depending on the factors that affect those who rely on agricultural production. Flückiger and Ludwig (2017) show that the process of urbanisation is associated with fertility transitions and increased investment in children's education. Nevertheless, it is understandable, given that the growth of the urban population will increase the rate of population growth.

\section{Data and methodology}

\section{Data types and sources}

The aim is to analyse the relationship between income inequality and social variables using annual panel data over the period 2005-2018, which covers 33 provinces in Indonesia. This period is sufficient to get more observations, which the number of observations is 462 . One of the advantages of a panel data structure is that this study has more observations and degrees of freedom. This approach avoids the problem of false regression and offers a parsimonious panel data approach from a dynamic and broader structural model. Data were taken from the central bureau of statistics and for unemployment data collected from Bank Indonesia. Table 1. presents descriptive statistics of each variable.

Table 1. Descriptive statistics of variables

\begin{tabular}{|c|c|c|c|c|c|}
\hline Variable & Mean & Median & Maximum & Minimum $\quad \mathrm{S}$ & Standard Deviation \\
\hline Gini & 0.3502 & 0.3500 & 0.4600 & 0.2400 & 0.0458 \\
\hline lpop & 0.2415 & 0.1875 & 1.2619 & -0.5086 & 0.4352 \\
\hline lhealt & 1.4760 & 1.4827 & 1.6960 & 1.1894 & 0.0900 \\
\hline leduc & 1.7071 & 1.7195 & 1.8597 & 1.4435 & 0.0848 \\
\hline lhdi & 1.8534 & 1.8550 & 1.9068 & 1.7619 & 0.0231 \\
\hline lurb & 1.6562 & 1.6507 & 2.0000 & 1.1875 & 0.1669 \\
\hline linco & 4.3681 & 4.3921 & 5.3280 & 3.4511 & 0.3522 \\
\hline lw & 6.0081 & 5.9890 & 6.5247 & 5.5314 & 0.2042 \\
\hline lum & 0.7909 & 0.7877 & 1.2767 & 0.1716 & 0.1956 \\
\hline
\end{tabular}

Data source central bureau of statistics and Indonesian central banks for unemployment data.

The study analyses the long-term relationship between income inequality and social variables using panel data covering nine variables. The variable income inequality is the provincial Gini ratio. The next variable is social variables, which are population variables with provincial population growth and health variables that include the percentage of people with health complaints over the past month (indicated in percent), as well as, education which is pure high school enrollment rates. There are also, human development variable namely the human development index by province and the urbanisation variable which is the growth of the urban population by province. Other economic social variables are per capita income with indicators of regional gross domestic product per capita, and wage variables indicated by 
regional/provincial minimum wages and unemployment, namely the open unemployment rate by province.

\section{Model Specifications}

Based on theoretical and empirical information about identifying long-term relationships between income inequality and social variables, and following co-integration analysis techniques and estimation of long-term VECM or SVAR models Massidda and Mattana (2013), Cuestas (2017), and Bahal et al. (2018), structural model specifications ranging from VAR models to panel data as:

$$
Y_{i, t}=\sum_{k=1}^{q} \Psi_{k} Y_{i, t-k}+\Xi D_{i, t}+e_{i, t}
$$

where ' $i$ ' is a provincial unit, ' $q$ ' is the right sequence for the lag polynomial, $\Psi_{k}$ is a matrix containing parameters of interest, $e_{i, t}$ is a residual vector that can be observed, and $\Xi$ is the matrix coefficient associated with the deterministic term. $Y_{i, t}$ is a system variable, which represents the vector of social variables of this study, namely: $\left[\right.$ gini $_{t i,}$, pop $_{i, t}$, heal $_{i, t}, e d u c_{i, t}, h d i_{i, t}$, urb $\left._{i, t}\right]$, where, gini $i_{t i}$ is income inequality which measured by the Gini index, oop $_{i, t}$ is population, $h e a l_{i, t}$ is a health factor which is a population that has health complaints, and $e d u c_{i, t}$ is education measured in pure high school participation rates, $h d i_{i, t}$ is a human development index by province, and $u r b_{i, t}$ is urbanisation factor measured by urban population growth. Plus macro variables namely, income per capita that measured as the ratio of real gross domestic product divided by total population $\left(\right.$ inco $\left._{i, t}\right)$, minimum wage $\left(w_{i, t}\right)$ and unemployment $\left(u m_{i, t}\right)$. It is assumed that the shocks. "educi,t-k, $h d i_{i, t-k}, w_{i, t-k}, u r b_{i, t-k}$ " is negative towards $g i n i_{i, t}$, meaning that of these variables reduces income inequality (Gini Index). Then shocks "heal $l_{i, t-k}$, pop $_{i, t-k}, u m_{i, t-k}$ " is positive, and "inco ${ }_{i, t-k}$ " can be positive or negative. When the variable is nonstationary, and there is cointegration between variables, equation (1) can be expressed in long-run representation by subtracting $Y_{t-1}$ from both sides. The model can be rewritten as follows:

$$
\Delta Y_{i, t}=\alpha \beta^{\prime} Y_{i, t-1}+\sum_{k=1}^{q} \Gamma_{k} \Delta Y_{i, t-k}+e_{i, t}
$$

where $\Gamma_{k}$ contains variable coefficients in differences (with $j$ denoting the lag sequence, with maximum pause $q$ ), $\beta^{\prime}$ is matrix $(Y \times r)$ long-term coefficient, with $r$ co-integration rank of the system. Blanchard and Quah (1989) the first to use structural vector auto-regression (SVAR) by limiting the long-term effects of various shocks. To identify structural innovations that induce the effects of structural shocks on system variables, one can write the following structural specifications:

$$
A \Delta Y_{i, t}=A \alpha \beta^{\prime} Y_{i, t-1}+A \sum_{k=1}^{q} \Gamma_{k} \Delta Y_{i, t-k}+\varepsilon_{i, t}
$$

where $\varepsilon_{i, t}$ is $(K \times 1)$ Structural interference vector with zero mean and covariance matrix $\sum \varepsilon$. Premultiplying system (2) by $A^{-1}$ give a reduced form of equation (2), where:

$$
e_{i, t}=A^{-1} \varepsilon_{i, t}=B \varepsilon_{i, t}
$$


$e_{i, t}$ is a reduced residual form $\left(e_{i t}^{k}\right)$, and $\varepsilon_{i, t}$ represent structural innovation $\left(\varepsilon_{i t}^{k}\right)$. Identification is usually achieved by imposing long-term restrictions on matrix B. Assuming that structural shocks are uncorrelated and have unit variance $\Sigma_{\varepsilon}=1_{K}$, by using equation (4), we get:

$$
\Sigma_{e_{i, t}}=E\left[e_{i, t} e_{i, t}^{\prime}\right]=B E\left[\varepsilon_{i, t} \varepsilon_{i, t}^{\prime} B^{\prime}=B \Sigma_{i, t} B^{\prime}=B B^{\prime}\right.
$$

This is based on the standard assumption that structural shocks are uncorrelated and have unit variance. The minimum number of limits required for the unique specification of the element $k^{2}$ of the matrix, B is equal to $k(k-1 / 2$ (Emami dan Adibpour, 2012).

After matrix B identified, impulse response analysis can be applied. This analysis illustrates the time profile of the effect of structural shocks on each system variable and turns out to be very useful for policy simulation exercises. Table 2. is matrix B summarising structural equations for the two models. Model 1, uses six variables, namely, income inequality, population, health, and education, human development index and urbanisation growth. Mode 2. uses seven variables, namely; income inequality, population, health, education, and income per capita, wages and unemployment. Based on the theoretical model of the relationship between income and social inequality, the functional form for each equation must be consistent with the limitation of block exogeneity and reflect information from previous theoretical studies or researches of SVAR.

Tabel 2. Summary of the structural equation from matrix B

\begin{tabular}{|c|c|c|c|c|c|c|c|}
\hline \multicolumn{8}{|l|}{ Model 1} \\
\hline & $\boldsymbol{\varepsilon}_{i t}^{g i n i}$ & $\varepsilon_{i t}^{p o p}$ & $\varepsilon_{i t}^{\text {heal }}$ & $\varepsilon_{i t}^{e d u c}$ & $\boldsymbol{\varepsilon}_{i t}^{h d i}$ & $\varepsilon_{i t}^{u r b}$ & \\
\hline$e_{i t}^{g i n i}$ & $*$ & $*$ & $*$ & $*$ & $*$ & $*$ & \\
\hline$e_{i t}^{p o p}$ & $*$ & $*$ & 0 & 0 & 0 & $*$ & \\
\hline$e_{i t}^{\text {heal }}$ & $*$ & $*$ & * & 0 & 0 & 0 & \\
\hline$e_{i t}^{e d u c}$ & $*$ & 0 & $*$ & $*$ & 0 & 0 & \\
\hline$e_{i t}^{h d i}$ & $*$ & 0 & 0 & $*$ & $*$ & 0 & \\
\hline$e_{i t}^{u r b}$ & $*$ & 0 & 0 & 0 & $*$ & $*$ & \\
\hline \multicolumn{8}{|l|}{ Model 2} \\
\hline & $\varepsilon_{i t}^{g i n i}$ & $\varepsilon_{i t}^{p o p}$ & $\varepsilon_{i t}^{\text {heal }}$ & $\varepsilon_{i t}^{e d u c}$ & $\varepsilon_{i t}^{\text {inco }}$ & $\boldsymbol{\varepsilon}_{i t}^{W}$ & $\boldsymbol{\varepsilon}_{i t}^{u m}$ \\
\hline$e_{i t}^{g i n i}$ & * & $*$ & $*$ & $*$ & $*$ & $*$ & $*$ \\
\hline$e_{i t}^{p o p}$ & $*$ & * & 0 & 0 & $*$ & 0 & 0 \\
\hline$e_{i t}^{\text {heal }}$ & $*$ & $*$ & $*$ & 0 & 0 & $*$ & 0 \\
\hline$e_{i t}^{e d u c}$ & $*$ & 0 & $*$ & $*$ & 0 & $*$ & 0 \\
\hline$e_{i t}^{i n c o}$ & $*$ & $*$ & 0 & 0 & $*$ & $*$ & 0 \\
\hline$e_{i t}^{w}$ & $*$ & 0 & 0 & 0 & $*$ & * & $*$ \\
\hline$e_{i t}^{u n e m}$ & $*$ & 0 & 0 & 0 & 0 & 0 & $*$ \\
\hline
\end{tabular}

Source: own compilation

The rows in Table 2 shows the dependent variable in each equation, and the column shows which variable appears as the explanatory variable in each equation. Star sign in cells Table 2 shows a simultaneous relationship or is an estimate of shocks from factors to the independent variables. The 0 sign representing the contemporary restrictions on the matrix $B_{0}$ while the green asterisk is the shock of the factors to the variable itself, which is $K 1$. 


\section{Result and discussion}

As the first step in the empirical analysis, panel unit root tests have been carried out for all variables and to avoid the problem of false regression, using the Augmented Dickey-Fuller (ADF) and Philips and Perron (PP) tests. The unit root test results are presented in Table 3. Based on the results obtained, there is one variable which not integrated from sequence zero or I (0), but all variables are integrated from sequence one or I (1); therefore, all variables considered here are stationary at the first deferent. In the second step, optimal lag testing, assuming a maximum lag sequence, the recommended optimal lag is 2 for diagnostic tests performed.

Tabel 3. Unit root test results

\begin{tabular}{|c|c|c|c|c|c|c|c|c|}
\hline \multirow{3}{*}{ Variable } & \multicolumn{4}{|c|}{ Level } & \multicolumn{4}{|c|}{ 1st difference } \\
\hline & \multicolumn{2}{|c|}{$\mathrm{ADF}$} & \multicolumn{2}{|c|}{ PP } & \multicolumn{2}{|c|}{$\mathrm{ADF}$} & \multicolumn{2}{|c|}{ PP } \\
\hline & Intercept & $\begin{array}{l}\text { Intercept and } \\
\text { trend }\end{array}$ & Intercept & $\begin{array}{l}\text { Intercept and } \\
\text { trend }\end{array}$ & Intercept & $\begin{array}{l}\text { Intercept and } \\
\text { trend }\end{array}$ & Intercept & $\begin{array}{l}\text { Intercept and } \\
\text { trend }\end{array}$ \\
\hline Gini & $141.326^{*}$ & 81.5697 & $173.894 *$ & $105.769 *$ & $274.342 *$ & $233.276^{*}$ & $349.299 *$ & $344.260^{*}$ \\
\hline Lpop & 96.2953* & $149.214^{*}$ & $107.921 *$ & $142.723^{*}$ & $379.751^{*}$ & $314.879 *$ & $438.179 *$ & $418.223^{*}$ \\
\hline lhealt & $113.705^{*}$ & $78.6555^{*}$ & $113.032^{*}$ & $87.3127 *$ & $206.566^{*}$ & $117.409^{*}$ & $222.671 *$ & $135.714 *$ \\
\hline Leduc & 18.3536 & $81.6984 * *$ & 15.2604 & 59.7338 & $102.454 *$ & $109.060 *$ & $199.853^{*}$ & $113.502^{*}$ \\
\hline Lhdi & 26.7535 & $179.457 *$ & $84.1206 * *$ & $354.725^{*}$ & $277.007^{*}$ & $357.084 *$ & $483.730 *$ & $447.991 *$ \\
\hline Lurb & 76.5795 & 66.0160 & $82.0459 * *$ & 67.0492 & $223.690^{*}$ & $144.581 *$ & 297.164* & $317.452^{*}$ \\
\hline Linco & 70.0428 & 58.0306 & 73.5641 & 60.3193 & $106.531 *$ & $89.6130 * *$ & $242.017 *$ & $233.131 *$ \\
\hline Lw & 29.4617 & $100.416^{*}$ & 51.2943 & 75.2792 & $189.911 *$ & $133.763 *$ & $220.471^{*}$ & $156.606^{*}$ \\
\hline Lumen & 79.7445 & 62.0180 & $119.562^{*}$ & $148.604 *$ & $318.512^{*}$ & $221.126^{*}$ & $427.056^{*}$ & $458.138^{*}$ \\
\hline
\end{tabular}

The next step is co-integration testing, for variables according to the Johansen method (Johansen 1988). Based on Table 4, the $\mathrm{H} 0$ rejection occurs because the test statistic value is greater than the critical value and the probability value is smaller than the significance level used at the five ranks for model 1, and six ranks for model 2. Therefore, it can be concluded that co-integration occurs or long-term relationship between variables in the two models.

Table 4. Trace test statistics

\begin{tabular}{|c|c|c|c|c|c|}
\hline \multirow[t]{7}{*}{ Model 1} & Rank & Eigenvalue & $\begin{array}{c}\text { Trace } \\
\text { Statistic }\end{array}$ & $\begin{array}{c}0.05 \\
\text { Critical Value } \\
\end{array}$ & Prob.** \\
\hline & $\mathrm{R}=0$ * & 0.607016 & 441.3729 & 83.93712 & 0.0001 \\
\hline & $\mathrm{R}=1 *$ & 0.229192 & 146.2328 & 60.06141 & 0.0000 \\
\hline & $\mathrm{R}=2 *$ & 0.076732 & 63.97293 & 40.17493 & 0.0001 \\
\hline & $\mathrm{R}=3 *$ & 0.060397 & 38.74468 & 24.27596 & 0.0004 \\
\hline & $\mathrm{R}=4^{*}$ & 0.050830 & 19.05851 & 12.32090 & 0.0032 \\
\hline & $\mathrm{R}=5$ & 0.008111 & 2.573490 & 4.129906 & 0.1284 \\
\hline \multirow[t]{7}{*}{ Model 2} & $\mathrm{R}=0$ * & 0.448591 & 330.3553 & 111.7805 & 0.0000 \\
\hline & $\mathrm{R}=1 *$ & 0.122624 & 136.8896 & 83.93712 & 0.0000 \\
\hline & $\mathrm{R}=2 *$ & 0.101699 & 94.37334 & 60.06141 & 0.0000 \\
\hline & $\mathrm{R}=3 *$ & 0.061754 & 59.51689 & 40.17493 & 0.0002 \\
\hline & $\mathrm{R}=4 *$ & 0.056337 & 38.80038 & 24.27596 & 0.0004 \\
\hline & $\mathrm{R}=5 *$ & 0.045185 & 19.95475 & 12.32090 & 0.0022 \\
\hline & $\mathrm{R}=6^{*}$ & 0.015048 & 4.927606 & 4.129906 & 0.0314 \\
\hline
\end{tabular}

Hypothesis (H0) does not occur cointegration or long-term relationship between variables.

$*$ denotes the rejection of the hypothesis at the level 0,05.**MacKinnon-Haug-Michelis (1999) p-values

Source: own calculation 
This SVAR modelling uses long-term restrictions because, by co-integration testing, we get a long-term relationship between variables. The long-term VAR structural methodology outlined above is used to produce a long-term structural impulse response function that captures the dynamic linkages between income inequality and social variables in all provinces of Indonesia. In this section, we use this estimated impulse response for two models. The analysis of impulse response functions tracks the impact of long-term shocks in the first model for income inequality (gini), population (lpop), health (lhealth), and education (leduc), human development variables, and urban development variables (lurb). The impulse response second model tracks the impact of long-term shocks for the variable income per capita (linco), variable wages $(l w)$, and unemployment (lunem).

Analysis of structural impulse response functions (IRFs) is carried out on innovations in the form of an increase in the value of one variable by one standard deviation at the beginning of the period which results in annual changes over 11 years against other variables. The selection of the 11-year study period after deducting two years lag is estimated to be appropriate to observe changes in external variables to the surprise innovation of internal variables. The IRFs analysis will explain the impact of the shock on one variable on another variable. Where in this analysis, we can see the long-term dynamic response of each variable if there is an absolute shock of one standard error in each equation. The impulse response function analysis also functions to see how long the influence lasts. The horizontal axis is the year, while the vertical axis shows the response value as a percentage. Results of first model 1 in Figure 2 shows the impulse response function as answers toward the description of the relationship between social variables and income inequality in Indonesia.

The result of the long-term structural impulse response function in Figure 2, is the response of social variables namely; population, health, education, human development and urbanisation growth to the shock of the inequality of income (Gini). Also, respond that shock with a positive trend for the population. This means that income inequality increases population growth because low-income segments are more oriented to the number of children, unlike the rich who prefer to improve the quality of children rather than quantity. This is certainly in line with Leibenstein (1963) who considers that the benefits of additional children to decrease when family income increases, this fact can be the reason why low-income families want to have more children in Indonesia. While the health variable responds to Gini shock with a positive trend until entering the 6th period and been reach a point of equilibrium but based on the results of model 2 the health respond positively to the shock Gini from the beginning of the period until the end of the simulation. This means that the response of deteriorating health to income inequality is positive but will be able to experience a tendency to descend in the long run. These results show that the health of the population is declining with income inequality in Indonesia, it is consistent with the results of the Karlsdotter et al. (2012), Pickett and Wilkinson (2015), and Matthew and Brodersen (2018). Meanwhile, it is responding to this shock with a negative trend for education, human development and urbanisation. Therefore the high of income inequality will cause a decrease in the level of education, human development, and growth of urbanisation in Indonesia. High income inequality reduces educational opportunities for lowincome classes. This fact is in line with studies for Kudasheva et al. (2015) and Marks (2015). However, income inequality also reduces the level of human development, and increasing income inequality will reduce the growth of urbanisation. 

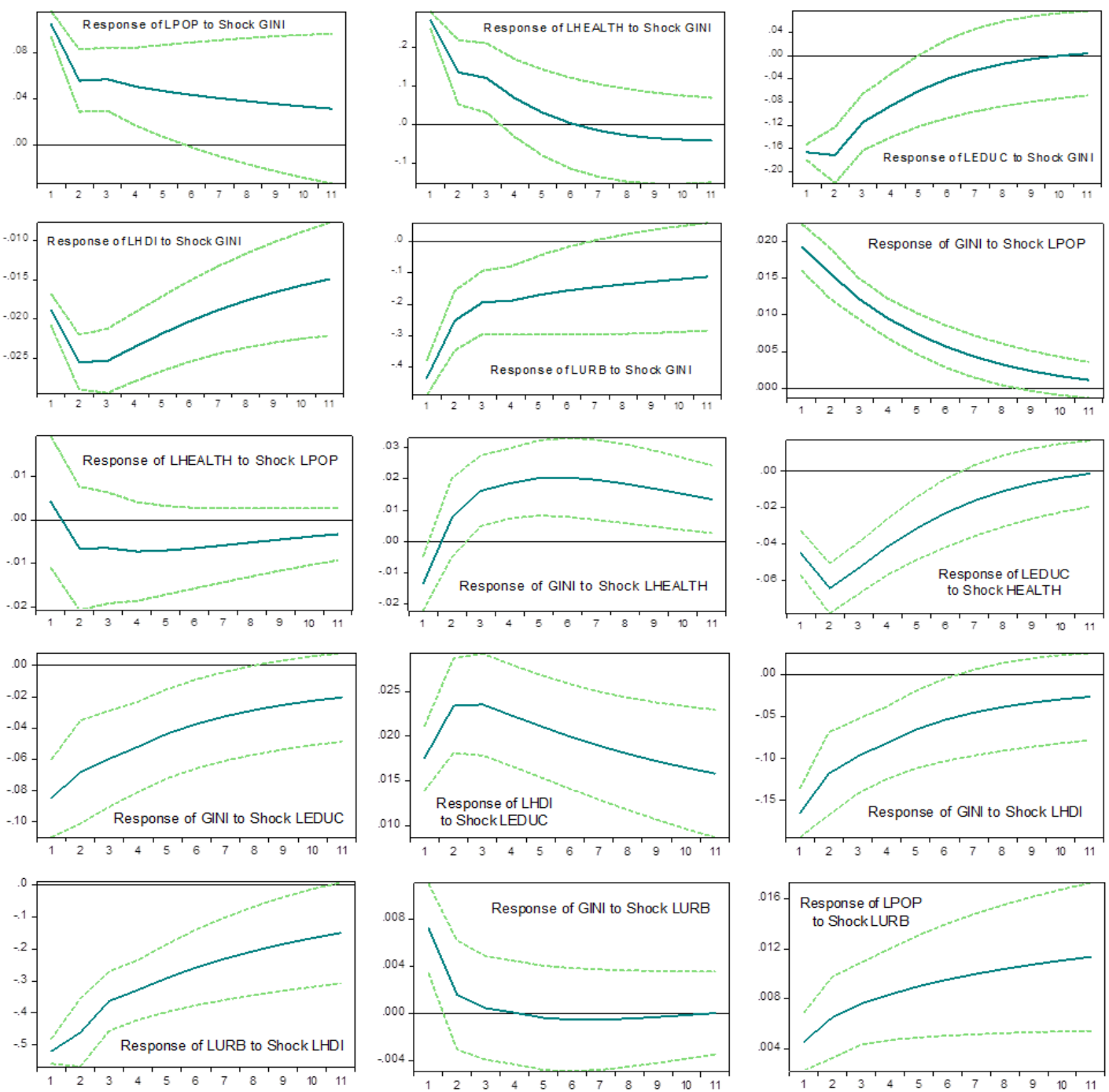

Figure 2. Results of impulse response function structural model 1.

Source: own compilation

The effect of population shock on the Gini index looks positive. Thus, an increase in population growth will cause increased income inequality. This is certainly in line with the assumptions put forward by Malthus, where an increase in the proportion of poverty is due to the increasing population. These results which determine the significant impact of population growth on income inequality reinforce the results obtained from the studies of Ram (1984) and Lee (2001). While population shock to health is insignificant, then the effect of health variable shock on income inequality looks positive. Thus, a decrease in the level of health will cause increased income inequality. It found that the spread of disease and poor health causes an increase in income inequality in Indonesia, agreeing with the relative income hypothesis and its supporters. Meanwhile, the health shock also had a negative impact on education, so a decline in health would cause education also to decline. Where if the children are in good health, making them increase the level of school attendance and cognitive development. This fact is consistent with Curtin and Nelson (1999), and Braakmann (2011).

The effect of education shock on the Gini index seems to be negative; the increase in education has an impact on decreasing income inequality. This is certainly understandable given that high education and achieving educational opportunities for the poor will reduce income inequality. These results find that family investment in education plays a vital role in 
explaining income inequality. These results are following Mariana, (2015), Campos et al. (2016), and Yang and Qiu (2016). Thus the effect of education shock on human development seems to be positive. Then the significantly increased education has an impact on increasing the human development index. This is certainly reasonable given that education increases human development. Meanwhile, the effect of human development shock on income inequality seems to be negative. This indicates that human development in Indonesia increases poor income, thereby reducing income inequality. This is also the case with its effects on urbanisation growth. It can be concluded that an increase in human development has an impact on falling income inequality and urban population growth. Surely, this can hit the result if the growth of the urban population decreases with increasing human development in Indonesia because families become more rational in choosing the quality over the number of their children.

While the effect of urbanisation growth shock on income inequality looks negative until the 4th period and then continues to move towards a state of equilibrium or near zero (convergence), this indicates that urbanisation growth has led to increased income inequality. That is mean, not as Kuznets claims that urbanisation growth reduces income inequality. According to Siddique and Wibowo (2014), if rural communities move to urban areas with little or no education and skills that are in line with workings demands of the city, then these people may be unemployed or may have to be involved in jobs with much lower wages. That is the reason why urbanisation growth has led to increased income inequality. These result also following the results of Qiu and Zhao (2019) and Sulemana et al. (2019). Also, we found the positive effect of urbanisation shock on the population. This is certainly understandable given the increase in urban population growth will increase population growth.

Figure 3. illustrates the impulses and responses estimated by variable income per capita, wages and unemployment. Effect of per capita income shock on income inequality seems to be positive, likewise that shock effect on population and unemployment. Thus per capita income causes increasing income inequality, resulting in increased population growth and unemployment in Indonesia. These results indicate a long-term relationship from per capita income to income inequality not negative as hypothesised by Kuznets. This is certainly in line with current conditions where Indonesia's per capita income is growing at the same time that income inequality is rising. Meanwhile, per capita income responded negatively to the shock of income inequality. These results are consistent with the results of the study of Thornton (2001), which found a long-term negative relationship from income inequality to income per capita, as hypothesised by Kuznets. Then also the per capita income response to the shock population looks negative. This is certainly understandable given the decline in per capita income if population growth rises. This fact is following Berg (2001) and Hasan (2010), who show that there is a negative relationship from population to per capita income.

Minimum wage shock effect on income inequality is negative. It can be concluded that minimum wages can reduce poverty, thereby reducing income inequality. This finding goes with the results of Bird and Manning (2008), Krozer et al. (2015), and Brito and Kerstenetzky (2019). Also, the effect of minimum wage shock is negative on health deterioration and positive on education. Consequently, the increase in the minimum wage leads to improved in the level of education and health, as asked by Askenazy (2003) and Ashta (2013), raising the standard of living for the working class with improving a minimum wage would mean more motivation to get more education and health both which lead to progressing the productivity. 
A. Taresh A, D. W. Sari,
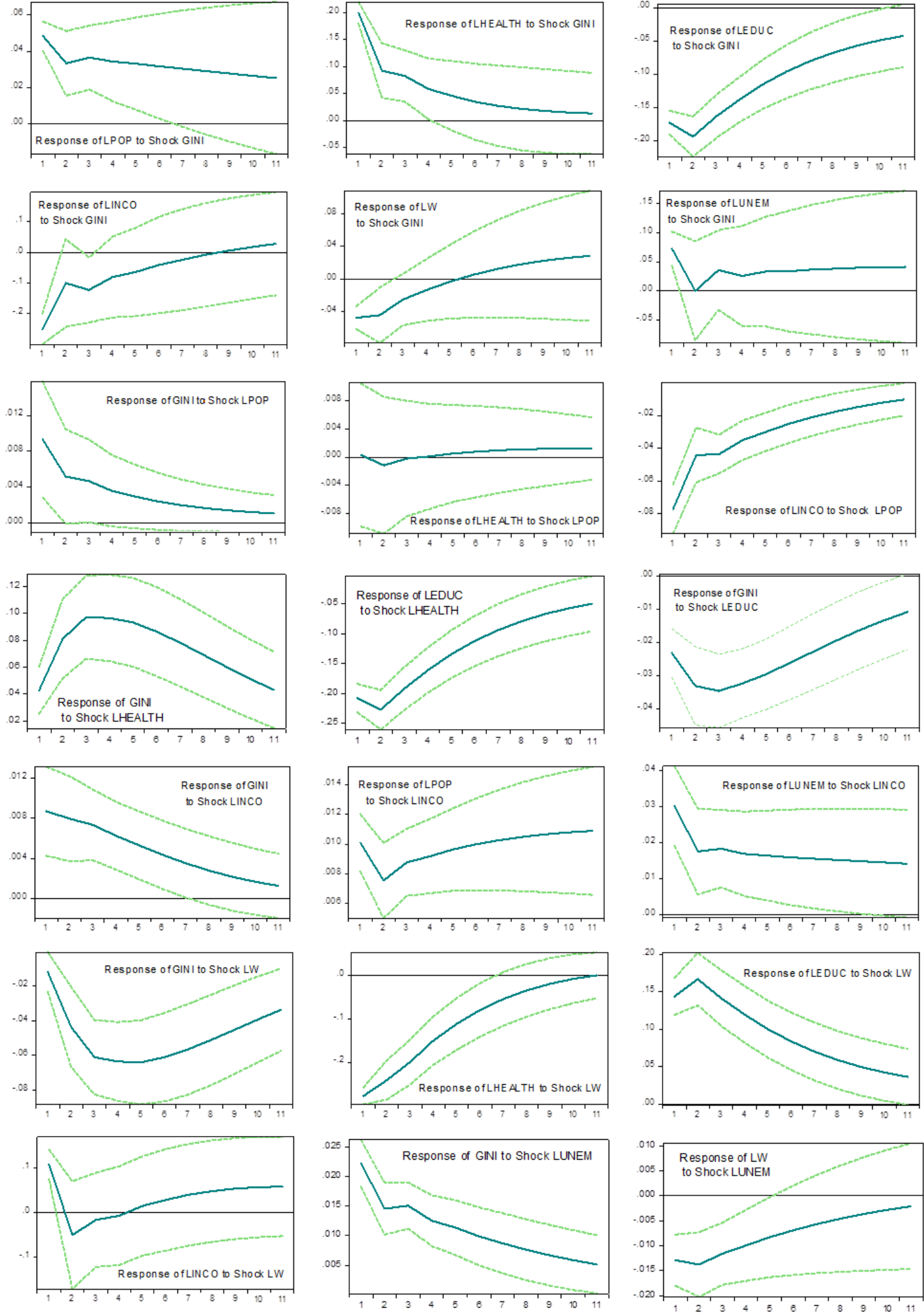

Figure 3. Results of impulse response function structural model 2.

Source: own compilation 
While the effect of minimum wage shock on per capita income looks positive in the first period then becomes negative in the second period until the 4th period, it continues to move towards the positive until the end of the simulation period. Means that increasing the minimum wage can increase per capita income with long periods. While the response of the minimum wage to the shock of income inequality appears the negative beginning of the period until the 5th period, and then continues to move towards the positive end of the simulation period. It justifies that income inequality decreases wage rates, but in the long run, the government is likely to try to resolve income inequality by raising minimum wages.

The effect of unemployment shock on income inequality is positive. Thus, unemployment responds positively to the shock of income inequality. Means that unemployment increases income inequality in Indonesia, at the same time income inequality increases unemployment as well. This finding is with the studies of Shahpari and Davoudi (2014), and Cysne and Turchick (2012), who find a positive correlation between unemployment and income inequality. Meanwhile, the effect of shock unemployment in response to the minimum wage is negative. This means that if unemployment is low, it will increase the minimum wage, this is according to Agénor and Lim (2018), and Adam and Moutos (2006), which revealed that in the long run, the reduction in the unemployment rate could create an increase in the minimum wage, if changes in the minimum wage are the result from political economy considerations.

\section{Conclusion}

This study found from the results of long-term impulse response analysis that income inequality affects social variables in Indonesia. The income inequality can increase population growth and unemployment. Low-income segments are more oriented to the benefits of the number of children rather than quality. Then income inequality can reduce the level of health and education, and reduce the human development index and urbanisation growth. Besides, social variables affect income inequality, where the population growth, unemployment, poor health and urbanisation growth can increase income inequality, but education and human development reduce income inequality in Indonesia. In addition, the results found that an increase in minimum wages can reduce income inequality and decreases the spread of diseases, also increases the level of education and income per capita. Then income inequality responds positively to the effect of per capita income shocks, however, Income inequality has a negative impact on per capita income.

Finally, the results of this study can be used as a reference for making economic and social development policies by the Indonesian government. The results show that the most effective alternative policy choices for reducing income inequality to achieve the welfare of all Indonesians is a reduction in unemployment accompanied by an increase in the minimum wages, coupled with a focus on the quality of the population in terms of increasing the level of health, education and human development.

\section{References}

Adam, A., \& Moutos, T. (2006). Minimum wages, inequality and unemployment. Economics Letters, 92(2), 170-176.

Agénor, P. R., \& Lim, K. Y. (2018). Unemployment, growth and welfare effects of labor market reforms. Journal of Macroeconomics, 58, 19-38.

Ashta, A. (2013). A minimum wage solution to halving world poverty by 2015: A stakeholder approach. IIMB Management Review, 25(1), 6-18. 
Askenazy, P. (2003). Minimum wage, exports and growth. European Economic Review, 47(1), 147-164.

Bahal, G., Raissi, M., \& Tulin, V. (2018). Crowding-out or crowding-in? Public and private investment in India. World Development, 109, 323-333.

Becker, G. S. (1981). A treatise on the family. enlarged. Harvard University Press, Cambridge Massachusetts, 15, 16-67.

Berg, H. V. d. (2001). Economic growth and development. Mc Graw-Hill, New York.: World Scientific.

Bird, K., \& Manning, C. (2008). Minimum wages and poverty in a developing country: Simulations from Indonesia's Household Survey. World Development, 36(5), 916-933.

Braakmann, N. (2011). The causal relationship between education, health and health related behaviour: Evidence from a natural experiment in England. Journal of Health Economics, 30(4), 753-763.

Brito, A. S., \& Kerstenetzky, C. L. (2019). Has the minimum wage policy been important for reducing poverty in Brazil? A decomposition analysis for the period from 2002 to 2013. EconomiA, 20(1), 27-43.

Blanchard, O., \& Quah, D., 1989. The dynamic effects of aggregate demand and supply disturbances. American Economic Review 79, 655-673.

Campano, F., \& Salvatore, D. (1988). Economic development, income inequality and Kuznets' U-shaped hypothesis. Journal of Policy Modeling, 10(2), 265-280.

Campos, B. C., Ren, Y., \& Petrick, M. (2016). The impact of education on income inequality between ethnic minorities and Han in China. China economic review, 41, 253-267.

Ciżkowicz, P., Kowalczuk, M., \& Rzońca, A. (2016). Heterogeneous determinants of local unemployment in Poland. Post-Communist Economies, 28(4), 487-519.

Cuestas, J. C. (2017). House prices and capital inflows in Spain during the boom: Evidence from a cointegrated VAR and a structural Bayesian VAR. Journal of Housing Economics, 37, 22-28.

Curtin, T. R. C., \& Nelson, E. A. S. (1999). Economic and health efficiency of education funding policy. Social Science \& Medicine, 48(11), 1599-1611.

Cysne, R. P., \& Turchick, D. (2012). Equilibrium unemployment-inequality correlation. Journal of Macroeconomics, 34(2), 454-469.

Detollenaere, J., Desmarest, A. S., Boeckxstaens, P., \& Willems, S. (2018). The link between income inequality and health in Europe, adding strength dimensions of primary care to the equation. Social Science \& Medicine, 201, 103-110.

Emami, K., \& Adibpour, M. (2012). Oil income shocks and economic growth in Iran. Economic Modelling, 29(5), 1774-1779.

Fazaalloh, A. M. (2019). Is foreign direct investment helpful to reduce income inequality in Indonesia?. Economics and Sociology, 12(3), 25-36.

Flückiger, M., \& Ludwig, M. (2017). Urbanization, fertility and child education in Sub-Saharan Africa. Economics Letters, 157, 97-102.

Gravelle, H., Wildman, J., \& Sutton, M. (2002). Income, income inequality and health: what can we learn from aggregate data?. Social science \& medicine, 54(4), 577-589.

Gindling, T. H., \& Terrell, K. (2010). Minimum wages, globalization, and poverty in Honduras. World Development, 38(6), 908-918.

Hasan, M. S. (2010). The long-run relationship between population and per capita income growth in China. Journal of Policy Modeling, 32(3), 355-372.

Izraeli, O., \& Murphy, K. J. (2003). The effect of industrial diversity on state unemployment rate and per capita income. The Annals of Regional Science, 37(1), 1-14. 
Johansen, S. (1988). Statistical analysis of cointegration vectors. Journal of economic dynamics and control, 12(2-3), 231-254.

Karlsdotter, K., Martín, J. J. M., \& del Amo González, M. P. L. (2012). Multilevel analysis of income, income inequalities and health in Spain. Social science \& medicine, 74(7), 1099-1106.

Krozer, A., Brid, M., Carlos, J., \& Rubio Badan, J. C. (2015). Inequality and minimum wage policy: Not even talking, much less walking in Mexico. Investigación económica, 74(293), 3-26.

Kudasheva, T., Kunitsa, S., \& Mukhamediyev, B. (2015). Effects of access to education and information-communication technology on income inequality in Kazakhstan. ProcediaSocial and Behavioral Sciences, 191, 940-947.

Kunze, L., \& Suppa, N. (2017). Bowling alone or bowling at all? The effect of unemployment on social participation. Journal of Economic Behavior \& Organization, 133, 213-235.

Kuznets, S. (1950). Conditions of statistical research. Journal of the American Statistical Association, 45(249), 1-14.

Kuznets, S. (1955). Economic growth and income inequality. The American economic review, 45(1), 1-28.

Kuznets, S. (1963). Quantitative aspects of the economic growth of nations: VIII. Distribution of income by size. Economic development and cultural change, 11(2, Part 2), 1-80.

Lee, M. R. (2001). Population growth, economic inequality, and homicide. Deviant Behavior, 22(6), 491-516.

Leibenstein, H. (1963). Population Growth and the Take-Off Hypothesis. In The Economics of Take-Off into Sustained Growth (pp. 170-184). Palgrave Macmillan, London.

Lise, J., Sudo, N., Suzuki, M., Yamada, K., \& Yamada, T. (2014). Wage, income and consumption inequality in Japan, 1981-2008: from boom to lost decades. Review of Economic Dynamics, 17(4), 582-612.

Lucas Jr, R. E. (1988). On the mechanics of economic development. Journal of monetary economics, 22(1), 3-42.

Lütkepohl, H. (2005). New introduction to multiple time series analysis: Springer Science \& Business Media.

Marks, Gary N. (2015). Education and Income Distribution. International Encyclopedia of the Social \& Behavioral Sciences.(Second Edition), Pages 132-136.

Mariana, I. (2015). Consequences of the investment in education as regards human capital. Procedia Economics and Finance, 23, 362-370.

Massidda, C., \& Mattana, P. (2013). A SVECM analysis of the relationship between international tourism arrivals, GDP and trade in Italy. Journal of Travel Research, 52(1), 93-105.

Matthew, P., \& Brodersen, D. M. (2018). Income inequality and health outcomes in the United States: An empirical analysis. The Social Science Journal, 55(4), 432-442.

Nelson, R. R. (1956). A theory of the low-level equilibrium trap in underdeveloped economies. The American Economic Review, 46(5), 894-908.

Nugraha, A. T., Prayitno, G., Situmorang, M. E., \& Nasution, A. (2020). The role of infrastructure in economic growth and income inequality in Indonesia. Economics and Sociology, 13(1), 102-115.

Paukert, F. (1973). Income distribution at different levels of development: A survey of evidence. Int'l Lab. Rev., 108, 97.

Pickett, K. E., \& Wilkinson, R. G. (2015). Income inequality and health: a causal review. Social Science \& Medicine, 128, 316-326. 
Qin, D., Cagas, M. A., Ducanes, G., He, X., Liu, R., \& Liu, S. (2009). Effects of income inequality on China's economic growth. Journal of Policy Modeling, 31(1), 69-86.

Qiu, L., \& Zhao, D. (2019). Urban inclusiveness and income inequality in China. Regional Science and Urban Economics, 74, 57-64.

Ram, R. (1984). Population increase, economic growth, educational inequality, and income distribution: Some recent evidence. Journal of Development Economics, 14(3), 419428.

Romer, P. M. (1986). Increasing returns and long-run growth. Journal of political economy, 94(5), 1002-1037.

Shahpari, G., \& Davoudi, P. (2014). Studying effects of human capital on income inequality in Iran. Procedia-Social and Behavioral Sciences, 109, 1386-1389.

Siddique, M. A. B., Wibowo, H., \& Wu, Y. (2014). Fiscal Decentralisation and Inequality in Indonesia: 1999-2008. University of Western Australia, Business School. Discussion Paper 14.22.

Sulemana, I., Nketiah-Amponsah, E., Codjoe, E. A., \& Andoh, J. A. N. (2019). Urbanization and income inequality in Sub-Saharan Africa. Sustainable Cities and Society, 48, 101544.

Thornton, J. (2001). The Kuznets inverted-U hypothesis: panel data evidence from 96 countries. Applied Economics Letters, 8(1), 15-16.

Wildman, J. (2003). Modelling health, income and income inequality: the impact of income inequality on health and health inequality. Journal of Health Economics, 22(4), 521538.

Wicaksono, E., Amir, H., \& Nugroho, A. (2017). The sources of income inequality in Indonesia: A regression-based inequality decomposition. ADBI Working Paper, No. 667, Asian Development Bank Institute (ADBI), Tokyo.

Wilkinson, R. G., \& Pickett, K. E. (2006). Income inequality and population health: a review and explanation of the evidence. Social science \& medicine, 62(7), 1768-1784.

Yang, J., \& Qiu, M. (2016). The impact of education on income inequality and intergenerational mobility. China Economic Review, 37, 110-125. 